\title{
The Death of Patriotism: Wilfre Owen's Dulce et Decorum Est as an Anti-War Manifesto
}

\section{A. Barış AĞIR*}

\begin{abstract}
Being one of the biggest fluctuations in world history, humanity had never seen an event such World War I that so completely convulsed its existing ideals. Collapsing the existing ethos, the war soon showed its potencies in art and aesthetic. It would be unimaginable that poetry stood indifferent to the massive carnage. The poets who witnessed fighting on the front lines inscribed their experiences into their literary lives and used poetry as a medium of opposing war. They shaped their works to criticize threats directed to humanity. With these pecularities, war poetry, an important move towards modern poetry, stands for a geniune disengagement from the previous naturalistic poetry and signals a change in 20th century thinking. Among war poets, Wilfred Owen is an important figure whose works juxtapose the expected and the actual circumstances of war and his best known poem Dulce Et Decorum is probable to be read as an anti-war manifesto.
\end{abstract}

Keywords: war, patriotism, shell-shock, poetry, anti-war

\footnotetext{
* Bursa Technical University, School of Foreign Languages.
} 


\section{Poetry, Patriotism and The Spirit of Modern War}

The soldiers who fought The First World War had an indescribable experience and internalised the shocking moments together with the blood clots. The men in the trenches psychologically and emotionally broke down and Those who were lucky enough to go back to home came upon a society totally far from their commitment and the consequences of the war caused psychological wounds."Their experiences on the front brought on hysteria, mental breakdown, muteness, paralysis, and other bizarre physical maladies" (Schilling, 2006: 5). World War I introduced these psychological smyptoms under the name of "shell-shock" which was seen in the body and pysche of soldier in various ways. "It is not clear whether the term 'shell-shock' was first invented by medical service personnel or if it was a soldier's phrase, but it was adopted not only by doctors and nurses but also by sympathisers and the war's opponents as describing any psychological trauma caused by the war" (Puissant, 2009: 134). In his book named Shell Shock Cinema, Anton Kaes writes about the background of the term "shell shock":

Although symptoms of shell shock -loss of vision, hearing, and speech; amnesia; paralysis; and sudden violent outbursts -had been reported in earlier wars, the term itself was not coined until about six months into the First World War. In February 1915, an article titled "Contribution to the Study of Shell Shock" appeared in The Lancet, the leading British medical journal, in which the military doctor Charles S. Myers described the blindness and memory loss that three frontline soldiers experienced after heavy shelling. Because no physical injury could be found, Myers speculated that the shock caused by bursting shells and exploding grenades brought about yet undetected physical changes (for instance, microscopic lesions) in the brain and spinal cord. Shell shock was understood here as a somatic condition, or basically a wartime variation of what in 1899 the German neurologist Hermann Oppenheim had termed "traumatic neurosis." (Kaes, 2009: 10)

This traumatic neurosis and shell shock were the keys in the literature of The First World War. Throughout the history of humanity, war has always affected the political, philosophical and literary representation of the ethos, because "the experience of violence puts tremendous pressure on nations, persons, ideas, and language" (Dawes, 2002: 131). As the first great, destructive event and a turning point in 20th century, The First World War influenced art and aesthetic deeply and caused transformations of them. "This first world war scored a profound disruption into prevailing standards of value and so opened the space in 
cultural time in which radical artistic experimentation would be fostered." (Sherry, 2005: $113)$.

The study of the First World War varies to many disciplines and one of them is literature including fiction, drama, poetry, memoirs, diaries, letters and journals. Claiming poetry as the art which protects human dignity most, it would be unimaginable that it stood indifferent to this massive carnage. Hence being one of the biggest fluctuations in the world history and collapsing the existing ethos, this "war made poetry happen" (Kendall, 2006: 2) and gave birth to many poets. "During World War I, every able-bodied man was expected to put on a uniform and fight for his country. The soldier-poet also was thrown into the trenches. Some of the most memorable poetry about real war by real men in uniform came from the English poets who fought in that war" (Reisman, 2011:2). The poets who witnessed fighting in the front inscribed their experiences into their literary lives and used poetry as a medium of opposing war. They shaped their works to criticize threats directed to humanity. "Soldier poets like Wilfred Owen often had to express the emotional aspects of their war experiences through a language restricted by stifling conventions and unsympathetic ideologies." (Schilling: 2006) As Gökmen quotes from Samuel Hynes:

A generation of innocent young man, their heads full of high abstractions like Honour, Glory, Heroism, Knighthood, Crusade and England, went off to war to make the world safe for democracy, peace and justice. They were slaughtered in senseless battles planned by stupid generals. Those who survived were shocked, disillusioned and embittered by their war experiences, and saw their real enemies were not the Germans, but the ole men at home who had lied them. They rejected the values and ideals of the society that had sent them to war, and in so doing separeted their own disillusioned generation from the past and from their cultural inheritance (Gökmen, 2011: 1).

The First World War reversed the past chivalric mode of patriotism and "led to a rupture between the traditional world in which fighting was still largely associated with chivalric ideals - with heroism and glory as in the diction of patriotic propaganda - and the rejection of these ideas due to the disillusionment that had already taken place during the war. (...) Much of what we today call 'antiwar poetry' is directed against the heroic glorification of death at war" (Puissant, 2009: 5-141). In war poetry, having been sent to front with romantic ideals such as heroism and glory, young men's crises are displayed as the collapsed forms of utopic world delusion. "In accordance with the official paradigm, the arm-chair pro-war poets presented the war as a continuation of a Homeric warrior tradition and upheld a knightly romance of a rigteous, patriotic and Goly crusade" (Gökmen, 2011: 38). This concept of romantic idealism were subversed by war time poets who "used their poetry of warning, 
realism and satire as a means to attack the old chivalric legends and official heroic myths of the war" (Gökmen, 2011: 115). Dealing with the themes like dilemmas of modern man, objecting religion and questioning the existence of God, inessentiality of political systems..., war poetry is an important move on the way to modern poetry which stands for a disengagement from the previous naturalistic one and signals a change in the 20th century poetical thinking. Because the First World War wittnessed a new form of warfare -such as trench, toxic gas, aviation, machine guns-, the expression of nature in poetry also changed and the nature which heals mind and soul turned into a disastrous area and the symbol of terror, thus became a "waste land". Therefore, the war poetry is a "a movement from the pastoral world of the Georgian poets to the bleak sarcasm of those poets who tried to overcome the war's incommunicability" (Puissant, 2009: 5). "Poets who witnessed this war, like Siegfried Sassoon, Rupert Brooke, and Wilfred Owen, among others, could not simply write poetry which celebrated nature: the terrible experience of war left its thumbprint on their thinking as well as on their imagination" (Baker, 2007: 125). "As traditional techniques and conventional heroic rhetoric were inadequate to convey the modern tragedy, (...) anti-war poetry introduced realism, colloquial language and directness of statement to poetry" (Gökmen, 2011: 82). Puissant explains the language of war poetry as below:

Both traditional vocabulary and poetic style became inadequate when confronted with front-line experience surpassing everything known up to that time. Above all, the war reversed the idea of progress that had dominated nineteenth-century British thinking. Modern warfare forced many authors to adapt their notions of poetry to the new situation and reject those abstractions that made war seem familiar. In order to grasp the ambivalent situation of modern war, poets drew back on various poetic means of expressing ambiguity. In addition to irony and its enhanced form of sarcasm, cynicism, satire and parody were among those frequently used stylistic devices to comment on the absurdity of war. They often took on a cathartic role to counter the tensions, fear and grief of front-line experiences by allowing the expression of personal attitudes towards war. (Puissant, 2009: 4)

This language of war poetry highlights a variety of themes such as sufferings and pains, death, harassment of soldiers, violence, destruction, uproar against mechanized arms and weapons. Modern war poetry portrays the scene of trenches, smoke, bombardment, attack, bloodshed, ugliness and death. Ahmed Abu Baker summarizes characteristics of war poetry as below:

We find that most modern war poetry deals with the brutality and atrocities of war. The poets try to change the favorable attitude of some people towards war by exploring in depth the spiritual hell that war brings into being, and by describing the physical and the 
emotional pain which humans have to endure during and after the war. The terror, ugliness, and brutality of war became a major theme in the poetry of war poets like Siegfried Sassoon and Wilfred Owen, whose first-hand experience of war made their poems lifelike representations of the ugly face of war (Baker, 2007: 126).

\section{An Anti War Manifesto: Dulce Et Decorum Est}

Written his most important poems that carried him onto great poets canon between 1917-1918, war poet Wifred Owen is known as portraying war atmosphere utmost factual. As Rawlinson quotes from Ian Hamilton, "it was the war experience, the unanticipated horror of trench-combat, that turned him into the poet we now value so highly" (Rawlinson, 2007: 114). According to Reisman, "Wilfred Owen exhibited more potential to continue and enlarge the craft of poetry than any of the soldier-poets of World War I" (Reisman, 2011: 138). As a person who witnessed barbarity of the battle inside the front, Owen juxtaposes expected and founded situations of war in his works and presents the reality of war to the memory of humanity. Santanu Das refers to this memory of war through some images that can be found in war poetry: "Darkness, guns, mud, rain, gas, bullets, shells, barbed wire, rats, lice, cold, trench foot: these images which have formed the modern memory of the war are largely culled from the trench poetry of Owen, Sassoon, Graves, and Rosenberg expressing the truth of war" (Das, 2007: 76). Gaining their powers from this reality and "fusing aesthetics with ethics, poetry with pity" (Longley, 2005: 71), Owen's poems are like scenes of a dramatic play that depictures suffering of war. Instead of big political declamations, his poems present stories in which we see physical and pyschological struggles of soldiers and their embodied pain. Daniel Hipp states that;

As a civilian, it was possible, if not to ignore the war, then surely to misrepresent it in terms of the values it seemed to represent when it began. As a soldier, however, Owen came to see, as did most other soldiers, the emptiness of these stances and the impracticality of his inherited Victorian elitism. As a poet who would soon find himself recovering from shell shock, he sought to replace these values with an under-standing of an alternative and personal purpose for the fighting ( Hipp, 2002: 26).

Although his poems are based on the ideals of the Romantics, they also emphasize "the distinction between literature of beauty and of war" (O'Keeffe, 1972: 55). His poems focuse on the lives and deaths of soldiers and they are like dramatic scenes that carry battlefield on to the stage. His most famous poem Dulce et Decorum Est was written towards the end of war while he was staying in Craiglockhart Hospital because of the shell shock. Written by the influence of daring style of another war poet Siegfried Sassoon, whom Owen 
met at the hospital, the poem stands out, at first blush, with the richness of imagery it comprises. Thematically, we encounter with a poet who acknowledged to lose out in this world: The life ended, values like the belief of God, nationalism, hope, civilisation have already become a lie. "The title comes from a Latin phrase in Horace, meaning "It is sweet and meet to die for one's country. Sweet! And Decorous!"; this title suggests that Owen sought to do more than chronicle the event. His goal was to attack the concept that sacrifice is sacred; he hoped to destroy the glamorized decency of the war" (Bloom, 2002: 15).

Dulce et Decorum Est presents a scene from soldiers who were sent to war with a strong nationalist idea, but had to face with the horrible reality. In the poem, a moment of war in which a group of soldiers are included is staged. The poem consists of three stages, each dealing with a different experience. It opens with the lines depicting the reality of war:

Bent double, like old beggars under sacks,

Knock-kneed, coughing like hags, we cursed through sludge,

Till on the haunting flares we turned our backs

And towards our distant rest began to trudge (55).

In the first stanza, fallen from power and become deppressed state of mind, the conditions of soldiers unite with the symbols of senility and deficiency, thus depicture unavoidable pain and they suffer from the symptoms of shell shock. "Bent double like old beggars" and "coughing like hags", these soldiers are bodily deformed and walking to a space where they can take rest without thinking of any ideal of heroism. Owen here criticizes the propoganda of the government and gives us a true picture of poor mental and physical state of the soldiers which "provide us with the unvarnished and unpopular truth of military action that has heretofore been hidden from civilian experience" (Jampbell, 2005: 265).

The First World War was a battle in which chemical weapons were intensively used to demoralize and injure. In 1917, Germans used the most effective chemical gas called "mustard gas" against British soldiers. It was a liquid and its main principle use was to incapacitate the enemy. Because of this gas, mays soldiers died in agony, many of them suffered from skin blusters and damaged lungs. "It was a terrifying everyday event that the soldier poet found a way to transform into poetry" (Riseman: 2011: 2). With the beginning of chemical war, British improved mass production of gas masks to protect the army, even dogs and horses wore gas masks. Owen speaks of his gas experience when he describes watching a doomed soldier drowning as his lungs filled with fluid. In the second part of the poem, the soldiers are staggered with a sudden gas attack and save their lives with great difficulty. At 
this point the narrative voice punctuates and notices that one of the soldiers did not manage to wear his mask and was separated from the group. This is the turning point that acridly changes the line of the poem:

Gas! GAS! Quick, boys!-An ecstasy of fumbling

Fitting the clumsy helmets just in time,

But someone still was yelling out and stumbling

And flound'ring like a man in fire or lime.-

Dim through the misty panes and thick green light,

As under a green sea, I saw him drowning (55).

Starting stanza with first in lower case and then in capitals, Owen alarms both the soldiers and readers against gas attack. Shocked and desperated, this soldier is on the fine line between life and death and "fascination with death mingles with disgustand fear, as well as anger for the waste of life" (Puissant, 2009: 141). The word "drowning" implies that this soldier is drowning in his bodily fluids. Witnessing the last moments and creepy death agony of this straggler, narrative voice (or the persona) remarks the nature of gas with the images of "green light" and "gren sea" and with portraying a delphic underworld, he is in the manner that it is too late for salvation. In the last stanza, we see that, unable to stop his suffering, soldiers put their comrade into a wagon and the poem becomes a challenging question posed to the reader. Rendered with the voices of violence and death, this dreamlike scene, which is between reality and fantasy, will never pester the narrative voice and turn into nightmare with surrounding his dreams.

In conclusion, this poem symbolizes the ravaged system of values and the physical and pyschological miseries of war are depictured in successful representations. Owen is very successful when he narrates the crisis of a group of soldiers and and the crisis of a single individual at the same time. "The poem's conflict occurs particularly in the relationship between its first and second halves, between the speaker and the soldier, between past and present, and between Owen and his directly-addressed audience" (Hipp, 2002: 34). With the phrase "If you could hear", Owen canalizes his poem outwards and includes the reader into it. Thus he harasses them and creates an awakening poem. "Ending the poem with justified anger at 'The old Lie' of patriotism that led him and other young men to battle shows that Owen's personal struggle is far from over" (Hipp, 2002: 39). 


\section{References}

Abu Baker, A. (2007). "The Theme of Futility in War Poetry”. Nebula, 4.3. pp.125-140

Bloom, H. (2002). Poets of World War I: Wilfred Owen and Isaac Rosenberg. California: Chelsea House Publishers.

Campbell, J. (2005). Interpreting the War. Cambridge Companion to the Literature of the First World War. (Ed.) Vincent Sherry. Cambridge: Cambridge University Press. pp. 261279.

Das, S. (2007). War Poetry and The Realm of the Senses: Owen and Rosenberg. The Oxford Handbook of British and Irish War Poetry. (Ed.) Tim Kendall. New York: Oxford University Press. pp.73-99.

Dawes, J. (2002). The Language of War Literature and Culture in U.S. from the Civil War through World War II. Cambridge: Harvar University Press.

Gökmen, P. (2011). The War Poets and Wilfred Owen's Subversion of The Official Discourse of The War. Master's Thesis. Hacettepe University, Graduate School of Social Sciences, Ankara.

Hipp, D. (2002). "Wilfred Owen's War Poetry as Psychological Therapy". The Journal of the Midwest Modern Language Association, Vol. 35, No. 1, pp.25-49.

Jones, E. Wessely, S. (2006). Shell Shock to PTSD. Military Psychiatry from 1900 to the Gulf War. New York: Psychology Press.

Kaes, A. (2009). Shell Shock Cinema: Weimar Culture and the Wounds of War. New Jersey: Princeton University Press.

Kendall, T. (2006). Modern English War Poetry. New York: Oxford University Pres.

Longley, E. (2005). The Great War, History and the English Lyric. Cambridge Companion to the Literature of the First World War. (Ed.) Vincent Sherry. Cambridge: Cambridge University Press. pp.57-84. 
Norgate, P. (1989). "Wilfred Owen and the Soldier Poets". The Review of English Studies, New Series, Vol. 40, No. 160, pp. 516-530.

O’Keeffe, T. (1972). "Ironic Allusion in the Poetry of Wilfred Owen”. Ariel, Vol 3, No 4. pp.72-81.

Owen, W. (1963). The Collected Poems. (Ed). Edmund Blunden. New York: Twentyy-Third Printing

Puissant, S.C. (2009). Irony and the Poetry of the First World War. New York: Palgrave Macmillan.

Rawlinson, M. (2007). Wilfred Owen. The Oxford Handbook of British and Irish War Poetry. (Edited by) Tim Kendall. New York: Oxford University Press. 114-133.

Reisman, R.M.C. (2011). War Poets. Massachusetts: Salem Press.

Schilling, T.C. (2006). Wilfred Owen, Siegfried Sassoon, and the Great War Discourse on Shell Shock. Bachelor's Degree Thesis. Massachusetts Institute of Technology. Cambridge.

Sherry, V. (2005). The Great War and Literary Modernism in England. Cambridge Companion to the Literature of the First World War. (Ed.) Vincent Sherry. Cambridge: Cambridge University Press. pp. 113-137. 